\title{
Галстян Н.В. \\ Седативные препараты. Достоинство и недостатки препаратов на основе растительного сырья
}

Северо-Осетинский государственный университет имени К.Л Хетагурова

(Россия, Владикавказ)

doi: 10.18411/trnio-12-2021-311

Научный руководитель: Царахова Л.Н.

\section{Аннотация}

В настоящее время довольно стремительно растет количество заболеваний возникающих на фоне стрессовых ситуаций (неврозов). Встречаются неврозы весьма часто, но проявляются они не у всех одинаково. Причин для возникновения данных проблем огромное количество, ведь каждая небольшая проблема может служить толчком для возникновения нервного срыва. Самой главной причиной может послужить весьма длительное пребывание в конкретной или, так сказать определенной ситуации, которая не приятна человеку и приносит негативные эмоции. Как бороться с этим? Существует огромное количество лекарственных препаратов, которые несут положительную реакцию для организма в данной возникшей проблеме. Препараты основываются как на сырье синтетического, так и природного происхождения. У каждой группы препаратов существует большое количество, как плюсов, так и минусов. Препараты синтетического происхождения в свою очередь приносят больше вреда для здоровья человека, весь всем нам известно, что по сравнению с препаратами природного происхождения в них содержится больше вредных для нас компонентов. Препараты основанные на лек.сырье являются менее безвредными, ведь в них содержится минимум различных добавок, приносящих большое количество побочных реакций со стороны организма.

Ключевые слова: лекарственный препарат, плюсы, минусы, седативные, лек. Сырье.

\section{Abstract}

Currently, the number of diseases arising against the background of stressful situations (neuroses) is growing quite rapidly. Neuroses are very common, but they are not manifested in everyone in the same way. There are a huge number of reasons for these problems, because every small problem can serve as an impetus for a nervous breakdown. The most important reason may be a very long stay in a specific or, so to speak, a certain situation, which is not pleasant to a person and brings negative emotions. How to deal with this? There are a huge number of drugs that have a positive reaction for the body in this problem that has arisen. The preparations are based on both synthetic and natural raw materials. Each group of drugs has a large number of both pros and cons. Preparations of synthetic origin, in turn, bring more harm to human health, we all know that, in comparison with preparations of natural origin, they contain more components harmful to us. Preparations based on medicinal raw materials are less harmless, because they contain a minimum of various additives that bring a large number of side reactions from the body.

Keywords: medicinal product, pros, cons, sedatives, medicinal raw materials.

В настоящее время, практически каждый день мы сталкиваемся со множеством вопросов или проблем, которые так или иначе действуют на нашу нервную систему и вызывают, несмотря на наше желание частые эмоциональные перегрузки, а так же стрессовые состояния и переживания.

При возникновении чрезмерных раздражителей на ЦНС возможно такое явление, как срыв нервной деятельности, который объясняется преобладанием возбудительных процессов. В связи с этим на сегодняшний день на фармацевтическом рынке существует огромное количество успокаивающих препаратов, которые действую на центральную нервную систему, усиливая процессы торможения вызывают эффект течения нормальных 
психических процессов. Такие эмоциональные скачки, возникающие в процессе жизнедеятельности, вызывают огромное количество нежелательных для нас явлений, которые проявляются не только перенапряжениями, но и серьезными расстройствами со стороны нервной системы.

Люди наблюдают чувство беспокойства, которое возникают не по конкретному вопросу, но и просто так, без видимой на то причины, частые головные боли различной локализации, а так же интенсивности боли, бессонница, снижение или же наоборот повышение аппетита. Все эти явления могут приводить к тому что у человека сбивается ритм жизни, уменьшается его работоспособность, на фоне чего непроизвольно возникают и другие серьезные проблемы со здоровьем, которые напрямую связанны с центральной нервной системой, к таким можно отнести: вегетососудистые дистонии, неврастении, истерии и .д Актуальность данной проблемы привела к необходимости принятия препаратов, которые могли бы уменьшить симптомы, возникающие на фоне стрессовых состояний. Врачам стало необходимо назначать группу седативных средств - лекарственные средства, которые, усиливая процессы торможения в центральной нервной системе, оказывают общее успокаивающее действие. $\mathrm{B}$ сравнении с существующими на фармацевтическом рынке бензодиазепинами, седативные средства имеют эффект оказания менее выраженного антифобического эффекта, а также они не вызывают миорелаксации( снижение тонуса скелетных мышц) и атаксии. Это конечно же является плюсом для седативных средств. Высокий интерес к седативным средствам на основе ЛРС возник не только у врачей, но и пациентов, и объяснением к этому стало множество факторов. Нельзя не отметить то, что препараты на основе лек.сырья обладают меньшим количеством побочных эффектов, по сравнению с синтетическими препаратами, легче переносятся, не вызывают лекарственной зависимости и в меньшей степени вызывают снотворный эффект. Это так же объясняет тот факт, что с появлением на рынке большого количества синтетических препаратов не привело к спаду спроса на фитопрепараты.

Препараты на основе лекарственного сырья являются более старыми, их стали изготовлять и пользоваться еще в народной медицине. Лекарственно-растительное сырье оказывает успокаивающее действие, применяются также для профилактики сердечных и сосудистых заболеваний. Их успокаивающее действие связано с содержанием в них биологически активных веществ, которые препятствуют образованию атеросклеротических блящек и поддерживают тонус сосудов. При применении препаратов необходимыми курсами можно добиться весьма положительного эффекта.

Сед-ые препараты на основе ЛРС имеют большой спектр применения и назначаются врачами довольно часто. К плюсам препаратов можно отнести их высокую биодоступность, они довольно хорошо всасываются в двенадцатиперсной кишке благодаря высокой концентрации РН. Требованиями к препаратам седативного действия является: проявление как можно меньшего количества побочных эффектов, оказание расслабляющего, успокаивающего действия, снижение тревоги и беспокойства, а так же оказывать незначительное действие двигательные и мыслительные функции. Всем требованиям препараты на основе лек.сырья соответствуют и отказывают менее щадящее действия, являются более безопасными и эффективными. Для лечения невротических расстройств их применяют довольно чаще благодаря мягкому воздействию на организм. Водорастворимые метаболиты СП в основном выводятся почками, и даже малейшие нарушения функций органа на выведение препарата не влияет, это является одной из главных причин их широкого применения в медицине.

Нельзя не отметить важность проведения контроля за качеством сырья, используемого для изготовления фитопрепаратов, а точнее стандартизация ЛРС и совершенствование методов контроля качества. Малейшее наличие примесей может вызвать побочные эффекты на организм со стороны препараты, так как нельзя предсказать качество примесей. Важно так же правильное назначение препаратов специалистами и избежание самолечения, ведь насколько бы препараты не были щадящими и менее безвредными, чем 
синтетические лекарственные средства, нужно уметь правильно подобрать исходя из физиологический особенностей организма пациента, которому необходимо будет принять препарат, во-избежании побочных эффектов. В развитых странах в последнее десятилетие наблюдается рост принятие лекарственных растений седативного действия. Информация о составе, распространенности, примесей, внешних признаках, а так же о многом другом, что связано с конкретным лекарственным сырьем можно ознакомиться в Государственной Фармакопеи.

\section{$* * *$}

1. Блинков И.Л., Киселева Т.Л., Цветаева Е.В. Справочник по лечебному применению растений. Вып. 4.- М.: Марс, 1999.- $121 \mathrm{c.}$

2. Государственный реестр лекарственных средств, разрешенных к медицинскому применению. - М., 2002.

3. Государственная фармакопея РФ. XIV издание

4. Захаров Ю. А. "Лечение травами" Часть 1 и 2, М.: Школа - пресс, 1999 г. .- 65 с.

5. Муравьева М.А. Фармакогнозия (с основами биохимии лекарственных растений). - М: «Медицина», 1978. C. 657.

6. Попов А.П. Траволечебник: Лечение лекарственными травами. - СПб. Лейла, 1998. - 312

7. Сорокина А.А., Ермакова В.А., Зорин Е.Б.,Сергунова Е.В., Сапронова Н.Н.. Фармакогнозия. Учебная практика. Практическое руководство. Под редакцией Самылиной И.А., Сорокиной А.А.-М: МИА, 2011.432c.

8. Шульговский В.В. Физиология высшей нервной деятельности с основами нейробиологии: Учебник для студентов биологических специальностей вузов - М: «Академия», 2003. - С. 464.

\section{Гамаюнова Ю.А., Цека Ю.С., Чудакова Т.К., Тарасов В.С., Фоменко Д.А. Механизм поражения печени у больных инфекционным мононуклеозом различной этиологии}

Саратовский государственный медицинский университет (Россия, Саратов)

doi: 10.18411/trnio-12-2021-312

\section{Аннотация}

В статье рассматриваются основные патогенетические механизмы развития гепатитов при инфекционном мононуклеозе различной этиологии. Особое внимание уделено анализу различий в патогенезе повреждения печени основными возбудителями инфекционного мононуклеоза: цитомегаловируса, Эбштейна-Барр вируса. Проведен анализ современных данных, подтверждающих аутоиммунный компонент повреждения печени вирусом Эбштейна-Барр. В статье показаны механизмы сочетанного действия вирусов. Данный обзор позволит обосновать выраженность клинических проявлений гепатитов при инфекционном мононуклеозе смешанной этиологии.

Ключевые слова: инфекционный мононуклеоз, цитомегаловирус, вирус ЭбштейнаБарр, гепатит, дети.

\section{Abstract}

The article discusses the main pathogenetic mechanisms of hepatitis development in infectious mononucleosis of various etiologies. Special attention is paid to the analysis of differences in the pathogenesis of liver damage by the main pathogens of infectious mononucleosis: cytomegalovirus, Ebstein-Barr virus. The analysis of modern data confirming the autoimmune component of liver damage by the Epstein-Barr virus has been carried out. The article shows the mechanisms of the combined action of viruses. This review will allow to substantiate the severity of clinical manifestations of hepatitis in infectious mononucleosis of mixed etiology. children.

Keywords: infectious mononucleosis, cytomegalovirus, Epstein-Barr virus, hepatitis, 